\title{
ASIIAN (3) The Reproductive Biology of \\ FISHERIES \\ SCIENCE \\ Pachypterus khavalchor (Kulkarni, 1952) in the Panchaganga River of the Western Ghats, a Biodiversity Hotspot in India
}

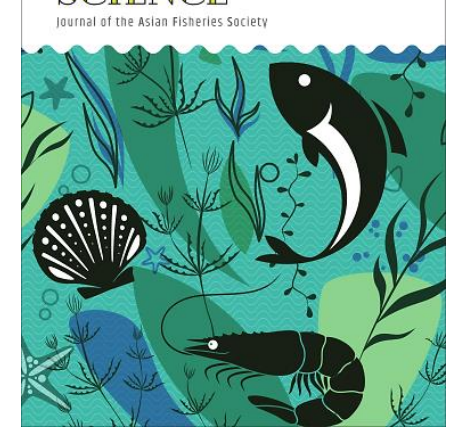

(C)Asian Fisheries Society

ISSN: 0116-6514

E-ISSN: 2073-3720

https://doi.org/10.33997/j.afs.2020.33.2.001

\author{
SACHIN M. GOSAVI ${ }^{1, *}$, SANJAY S. KHARAT ${ }^{2}$, SANDIP D. TAPKIR ${ }^{3,4}$, PRADEEP KUMKAR ${ }^{2,5}$ \\ 'Department of Zoology, Maharashtra College of Arts, Science and Commerce, 246-A, Jahangir Boman Behram Marg, Opp. Alexandra \\ Cinema, Nagpada, Mumbai 400 008, India \\ 2Department of Zoology, Modern College of Arts, Science and Commerce, Ganeshkhind, Pune 411 016, India \\ ${ }^{3}$ Department of Zoology, Savitribai Phule Pune University, Ganeshkhind, Pune, Maharashtra, 411 007, India \\ ${ }^{4}$ Biology Centre of the Czech Academy of Sciences, Institute of Hydrobiology, České Budêjovice, Czech Republic \\ ${ }^{5}$ Department of Zoology and Fisheries, Faculty of Agrobiology, Food, and Natural Resources, Czech University of Life Science Prague, \\ Czech Republic
}

*E-mail: schn.gosavi@gmail.com | Received: 09/11/2019; Accepted: 13/05/2020

\begin{abstract}
Pachypterus khavalchor (Kulkarni, 1952) is a rarely studied but highly exploited catfish species inhabiting the Krishna River system of India. A total of 427 fishes were collected monthly from the Panchaganga River to study its reproductive characteristics. Samples were analysed for length-weight morphometry, sexual dimorphism, gonad weight, and maturity status. Gonadosomatic Index (GSI), hepato-somatic Index (HSI), and stomach fullness index(SFI) were estimated to assess reproductive periodicity and its correlation with the fish condition and energy dynamics. Males had a cone-like genital papilla as a sexually dimorphic character. The male-female ratio was 1:1.02 (not different from 1:1) and females were comparatively larger than the males. Males matured at smaller sizes $(7.3 \mathrm{~cm})$ as compared to females $(8.9 \mathrm{~cm})$. The absolute fecundity varied from 932 to 24642 eggs.fish ${ }^{-1}$ while the relative fecundity ranged from 226 to $723 \mathrm{eggs.}$. $^{-1}$ of body weight. Regression analysis revealed a significant relationship between fecundity and ovary weight $(r=0.970)$. The GSI indicated that the breeding season for P. khavalchor is from April to August. The HSI and SFI showed that both males and females have similar seasonal reproductive patterns and feeding behaviour. Due to limited knowledge of its biology, its rare occurrence, and a highly fragmented population, the present study is likely to be useful in designing sustainable management and conservation plans for $P$. khavalchor.
\end{abstract}

Keywords: size at sexual maturity, lepidophagy, fecundity, catfish, spawning season

\section{Introduction}

Pachypterus khavalchor (Kulkarni, 1952) is a datadeficient, small freshwater catfish species inhabiting the rivers of the Western Ghats of India and is commonly known as "Khavalchor catfish" in English and "Khavalchor" in the local Marathi language (Dahanukar, 2011; Dahanukar et al., 2012; Froese and Pauly, 2018). The name of this species, 'khavalchor' (in Marathi 'khaval' = scale and 'chor' = thief), is derived from its scale-eating habit (Dahanukar et al., 2012; Gosavi et al., 2018). It is widely distributed in the Krishna River system and the middle Pennar River in Andhra Pradesh, India (Jadhav et al., 2011; Dahanukar et al., 2012; Froese and Pauly, 2018). This species has been reported in the state of Maharashtra from the Panchaganga River near Kolhapur, the Krishna River near Islampur and Sangli, the Koyna River near Patan, and the Indrayani River near Kamshet (Jadhav et al.,
2011; Dahanukar et al., 2012; Kumbar and Lad, 2014). It has also found in the Krishna River at Jamkhandi, and the Tunga-Bhadra River in the state of Karnataka and the Eastern Ghats of Andhra Pradesh (Dahanukar et al., 2012; Kumbar and Lad, 2014). In its natural habitat, P. khavalchor is well-known for its unique scale eating behaviour (lepidophagy) and plays a key role in maintaining the balance of the river ecosystem (Gosavi et al., 2018; 2019a; 2019b). Apart from its role in maintaining ecosystem balance, it also ensures nutritional and financial security of the local community by being an important component of the artisanal fishery sector (Jadhav et al., 2011; Gosavi et al., 2019b). However, over the past years, due to several anthropogenic stressors such as deterioration of water quality, overfishing, use of destructive fishing practices and pollution, most of the riverine habitats of $P$. khavalchor have been degraded resulting in the dramatic decline of the fish population (Gosavi et al., 
2019b). Menon (2004) indicated that $P$. khavalchor is a highly sensitive species and cannot cope with adverse changes in water quality parameters. Even minute changes in water quality will lead to the loss and recruitment failure of this species in the near future (Menon, 2004; Gosavi et al., 2019b). However, like other species inhabiting the rivers of the Western Ghats, there is a lack of information on life-history traits such as the reproductive biology of $P$. khavalchor. Thus, it is the need of the times to generate basic data on the reproductive biology of $P$. khavalchor, since information on the reproductive biology of fishes is fundamental for the conservation of species at risk and development of aquaculture for exploiting stocks (Turner, 1938; Olatunde, 1978; Bindu et al., 2012; Raghavan et al., 2016; Hossain et al., 2017; Ogunola et al., 2018).

The fundamental objective of the present study was to evaluate the reproductive biology of the khavalchor catfish on which little data is available. For this purpose, several parameters were estimated such as sex ratio, breeding season, size at first maturity, fecundity, stomach fullness index, hepatosomatic index, and condition factor for $P$. khavalchor in the Panchaganga River. The findings of this study would be useful for the implementation of conservation measures and the development of aquaculture of $P$. khavalchor.

\section{Materials and Methods}

\section{Study area}

The present study was undertaken in the Panchaganga River $\left(17.297^{\circ} \mathrm{N}\right.$ and $\left.74.175^{\circ} \mathrm{E}\right)$, a tributary of the Krishna River (Fig. 1). The Panchaganga River originates at Prayag Sangam in Chikhli, India, and flows into the Krishna River, Maharashtra. It is $80.7 \mathrm{~km}$ long and meets the Krishna river waterway at Narsobawadi, Maharashtra, India. A typical subtropical monsoon type characterises the climate of the study area. The study area receives rainfall from May to November due to its distinctive geographic location close to the Western Ghats of India. The monthly precipitation from May to November remains almost uniform and ranges between $25 \mathrm{~mm}$ and 50 $\mathrm{mm}$. The annual precipitation in the study area ranges from $508 \mathrm{~mm}$ to $6350 \mathrm{~mm}$. The temperature during monsoon season ranges between $19{ }^{\circ} \mathrm{C}$ and $30{ }^{\circ} \mathrm{C}$.

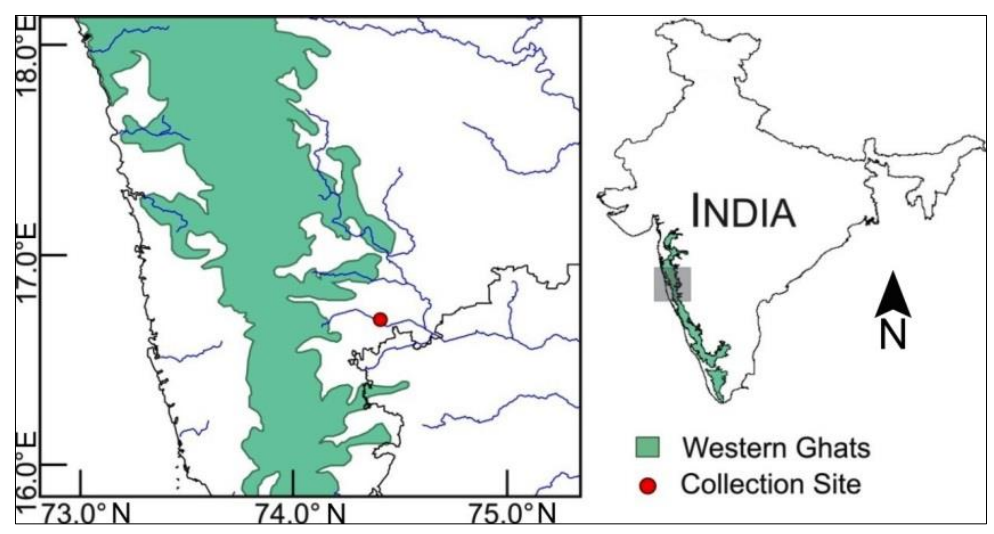

Fig. 1. Location of the study area for Pachypterus khavalchor in the Panchaganga River, northern Western Ghats, India.
Fish ( $n=427)$ were collected from commercial fisheries monthly from June 2015 to May 2016. The common fishing method employed by fishermen in this area mainly involves the use of nets with variable mesh sizes (mesh size $=1-2 \mathrm{~cm}$ ), such as gill nets and cast nets. The fishing nets are usually set overnight and retrieved the following morning. The fishes were immediately placed into ice-boxes and taken to a laboratory where they were analysed on the same day.

\section{Laboratory procedures}

Standard length (SL) and total length (TL) were measured for each individual to the nearest $0.1 \mathrm{~mm}$ using a digital vernier calliper (Mitutoyo, Japan). The weight ( $\mathrm{Wt}$ ) of each individual was determined to the closest $0.01 \mathrm{~g}$ using a digital weighing balance (Contech, India). Whole gonads were removed from each individual, weighed (GW) with a balance to an accuracy of $0.01 \mathrm{~g}$ and ovary length (OL) in $\mathrm{mm}$ was also measured.

The sex of each individual was determined by visual inspection and validated by dissection, followed by microscopic observation of the gonads. Males and females were segregated based on sexually dimorphic characters and the sex ratio was estimated. The breeding season was determined based on monthly variations of the gonadosomatic index (GSI) using the well-established formula:

$$
\text { GSI }(\%)=\frac{\text { Gonad weight }}{\text { Eviscerated body weight }} \times 100
$$

The hepatosomatic index (HSI) and stomach fullness index (SFI) were estimated using the following formulae:

$$
\begin{aligned}
& \text { HSI }(\%)=\frac{\text { Liver weight }}{\text { Eviscerated body weight }} \times 100 \\
& \text { SFI }(\%)=\frac{\text { Stomach content weight }}{\text { Body weight }} \times 100
\end{aligned}
$$

The relationship of GSI with HSI and SFI in males and females were tested by plotting the GSI against HSI and SFI. 
To estimate the size at $50 \%$ sexual maturity $\left(L_{50}\right)$, the proportion $(\mathrm{Pi})$ of mature individuals by sex and by length class were calculated:

$\mathrm{Pi}=\frac{\mathrm{Mi}}{\mathrm{Li}} \times 100$

where ' $\mathrm{Mi}$ ' is the number of mature individuals in the length class i and ' $\mathrm{Li}$ ' is the total number of individuals in the length class i. The obtained data were fitted to a logistical function that allows the precise estimation of $L_{50}$ that is required for fish stocks assessment. The equation used was as follows:

$P=A \times(1+e(-r \cdot(L t-L 50)))^{-1}$

where $L$ is the total length corresponding to the proportion $(P),{ }^{\prime} r$ ' is a constant that indicates the initial slope of the curve and $L_{50}$ is the length at which $50 \%$ of the individuals were mature.

The histological approach was also used to ascertain the maturity status. Tissue from testis and ovary of the dissected specimens were subjected to routine histological investigation using haematoxylin-eosin $(\mathrm{H}$ and E) stains. The stained slides were mounted permanently using DPX and were observed and photographed under a light microscope (Primo Star ZPS-0057, Zeiss, Germany) mounted with a digital camera (Tucsen ISH500, China). The maturity status was determined following the criterion given by Brown-Peterson et al. (2011).

Females bigger than or equal in size to sexually matured were randomly selected to determine the fecundity by the gravimetric method (Simpson, 1959). Ovaries were dissected and then preserved in $5 \%$ formalin solution for $24 \mathrm{~h}$ to allow the eggs to swell up for easy calculations. The total number of eggs in the ovary was calculated as a proportion. A subsection of the ovaries was weighed $(1 \mathrm{~g})$ and the number of eggs were counted. Fecundity $(F)$ was finally calculated using the following formula:

$\mathrm{F}=\mathrm{n} \times \mathrm{OW}$

where OW is the total weight of ovary in $\mathrm{g}$ and ' $\mathrm{n}$ ' is the number of eggs. $\mathrm{g}^{-1}$ of ovary.

Relative fecundity was determined by the ratio of the total number of eggs per unit weight of fish. A relationship between absolute fecundity and standard length (SL), body weight (Wt), ovary length (OL) and ovary weight (OW) was determined using the following equations: $\log F=\log (a)+b \log (S L) ; \log F=\log (a)+b$ $\log (W t) ; \log F=\log (a)+b \log (O L)$ and $\log F=\log (a)+$ $b$ log (OW) respectively; where, ' $a$ ' and ' $b$ ' are regression constants. The correlation between the standard length and the relative fecundity (to understand whether the larger females are really more fecund) was tested by plotting the standard length of the fish against the relative fecundity.

The fish condition was assessed using the following equation given by Ricker (1975):

$\mathrm{K}=\frac{\text { Wet weight }}{\text { Expected weight }} \times 100$

where the expected weight is the fish weight obtained from the length-weight relationship according to its body length (Froese, 2006). The condition index (K) was then estimated as the actual weight of the fish (real weight) as a proportion of its expected weight (theoretical weight).

\section{Statistical analysis}

Normality (using Shapiro-Wilk's test) and homoscedasticity (using Levene's test) were tested prior to analyses. Due to the non-normal distribution of data, the difference between male and female SL, $T L$, and Wt was estimated using Mann-Whitney Utest. The sex ratio was analysed using Chi-square $\left(\chi^{2}\right)$ test with the null hypothesis that the sex ratio is $1: 1$. Monthly variation in GSI, HSI, and SFI were analysed using Kruskal-Wallis test followed by Mann-Whitney U-test for using Bonferroni correction for multiple pairwise comparisons. Seasonal variation in the condition index was analysed using a one-way ANOVA followed by Tukey's test for multiple pairwise comparisons. The statistical software PAST (version 3.18) was used for data analysis (Hammer et al., 2001). The level of significance $(\alpha)$ was set at 0.05 .

\section{Results}

\section{Sexual dimorphism, sex ratio and distribution of sexes}

Males of $P$. khavalchor had cone-like genital papilla which can be considered as a sexually dimorphic character (Fig. 2a). They were small, fleshy, pointed, and broad-based structures (Fig. 2b). The genital papillae were more prominent during the breeding season.

A total of 427 P. khavalchor individuals were collected from the Panchaganga River with 211 (49.41\%) males and $216(50.59 \%)$ females. The overall sex ratio (male to female) of 1:1.02 was not significantly different from the expected ratio of $1: 1\left(\chi^{2}=0.059 ; P=0.8088\right.$; Fig. 3). However, a female biased ratio was observed in January $\left(\chi^{2}=13.06 ; P=0.0003 ;\right.$ Fig. 3$)$, September $\left(\chi^{2}=4.84 ; P=0.0278 ;\right.$ Fig. 3$)$ and November $\left(\chi^{2}=14.22\right.$; $P=0.0002$; Fig. 3) whereas a male biased ratio was observed in August ( $\chi^{2}=35.28 ; P=0.0001$; Fig. 3 ) and $\operatorname{October}\left(\chi^{2}=19.88 ; P=0.0001 ;\right.$ Fig. 3). 


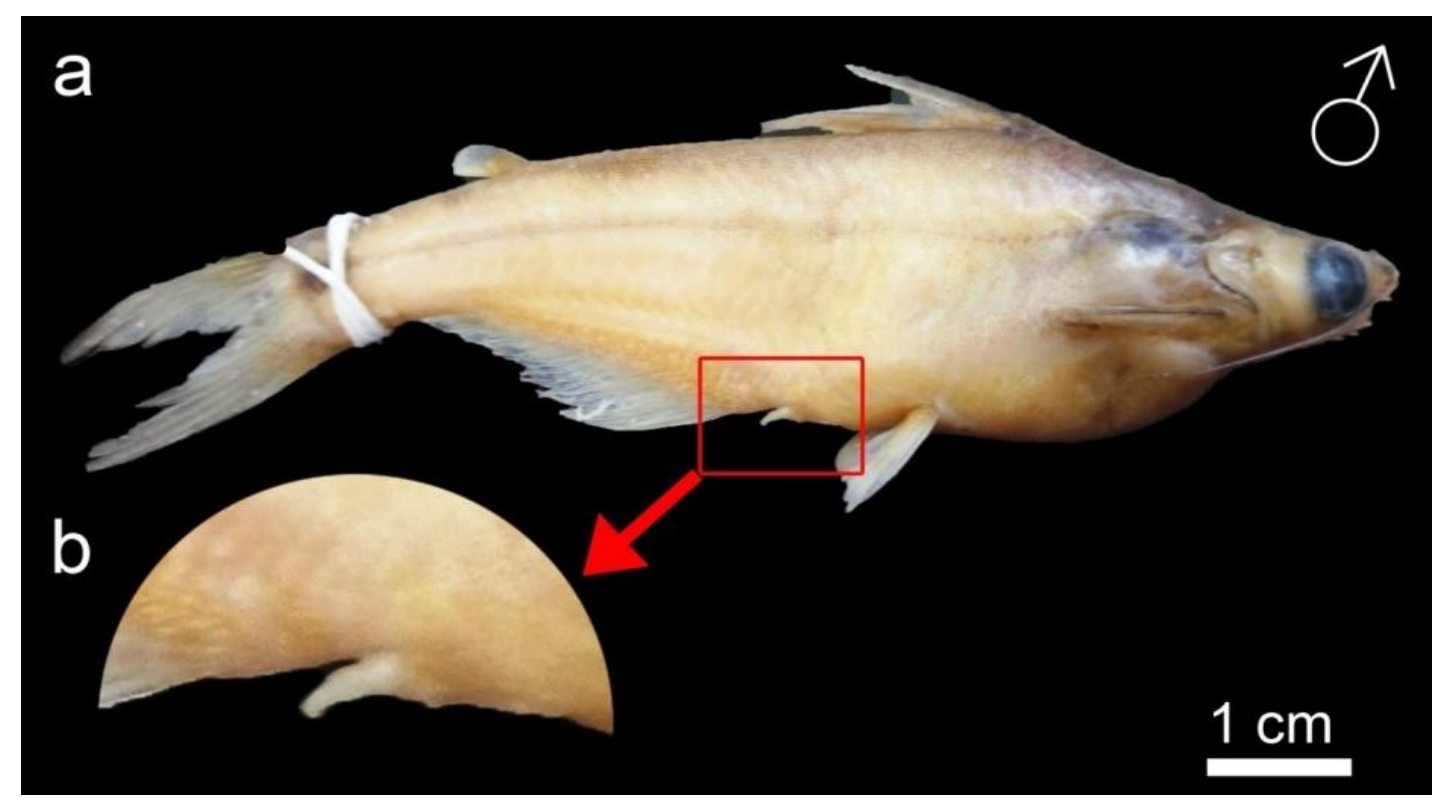

Fig. 2. a) Male of Pachypterus khavalchor with sexually dimorphic character; b) Enlarged view of the cone-shaped genital papilla.

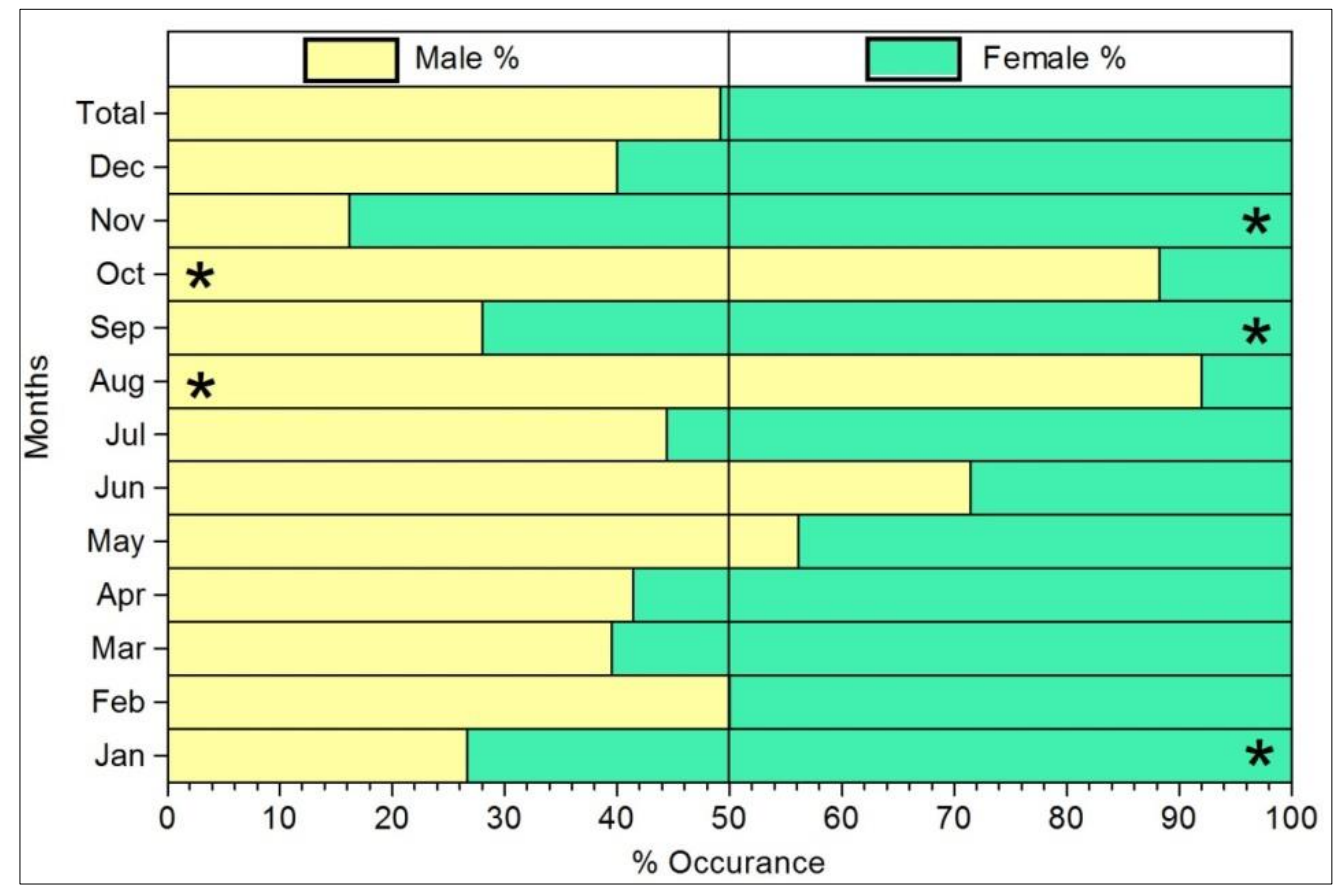

Fig. 3. Monthly sex ratio of Pachypterus khavalchor. The vertical line indicates the 1:1 proportion of males and females. *indicates that the sex ratio is significantly biased.

Females were found to be significantly larger and heavier than males (Mann-Whitney U-test; SL: $U=$ 14623; $P=0.0001 ; \mathrm{TL}: U=15719 ; P=0.0001$ and $\mathrm{Wt}: U=$ 16271; $P=0.0001 ;$ Table 1).

\section{Gonadosomatic index(GSI)}

A significant difference was observed in the GSI of females across the year (Kruskal-Wallis test, $H=175.7$; $P=0.0001$; Fig. 4a). The GSI range calculated for $P$. khavalchor females was $0.46-15.74 \%$. The GSI of females was the highest in April $(15.74 \pm 0.81 \%)$ and the lowest $(0.46 \pm 0.03 \%)$ in December (Fig. 4a).
Significantly higher values of the GSI (Mann-Whitney test; $P<0.01)$ were obtained from March to August (Fig. 4a). In males, a similar trend was observed with a significant difference in the GSI across the year (Kruskal-Wallis test, $H=153.8 ; P=0.0001$; Fig. 4b). The GSI range calculated for males was $0.09-1.47 \%$ with the highest in June $(1.47 \pm 0.05 \%)$ and the lowest $(0.09 \pm 0.003 \%)$ in December (Fig. 4b). Significantly higher values of the GSI (Mann-Whitney test; $P<0.01$ ) were obtained from April to August (Fig. 4b). 


\begin{tabular}{lllll} 
& & $S L(\mathrm{~cm})$ & $T L(\mathrm{~cm})$ & Wt $(\mathrm{g})$ \\
\hline Sex & $n$ & $($ Min-Max $) \pm S E$ & $($ Min-Max $) \pm S E$ & $($ Min-Max $) \pm S E$ \\
\hline Male & 211 & $(5.74-11.63) \pm 0.94$ & $(7.20-14.74) \pm 1.21$ & $(2.43-30.10) \pm 0.47$ \\
Female & 216 & $(6.57-14.23) \pm 0.99^{*}$ & $(7.95-17.05) \pm 1.19^{*}$ & $(3.62-46.46) \pm 0.49 *$ \\
\hline
\end{tabular}

* indicates significant difference between the morphological parameters.

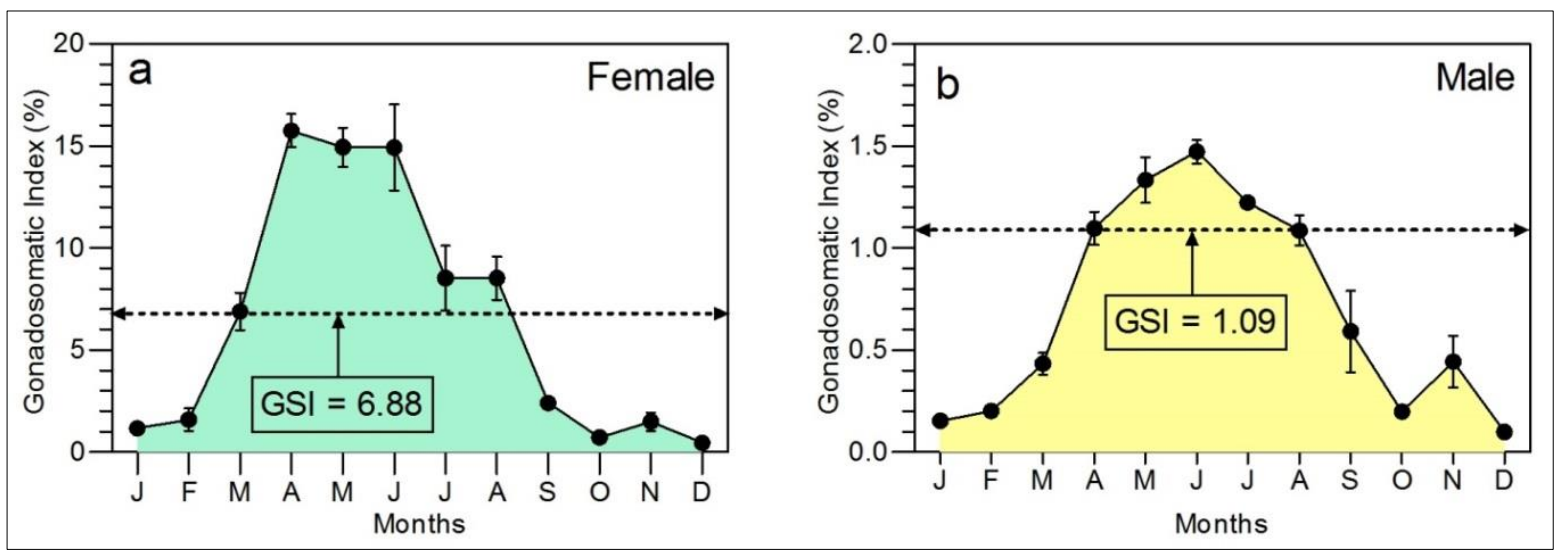

Fig. 4. Monthly patterns in the gonadosomatic index of a) females and b) males of Pachypterus khavalchor. The values on or above the horizontal black dotted lines are statistically significant.

\section{Hepatosomatic index (HSI)}

The HSI was roughly comparable in males and females outside the reproductive season but a distinct trend was found during the breeding season. A significant difference was observed in the female $\mathrm{HSI}$ across the year (Kruskal-Wallis test, $H=86.7 ; P=0.0001$; Fig. 5a). The HSI for $P$. khavalchor females ranged from 0.55 $1.35 \%$. The HSI of females was negatively correlated to the GSI (Fig. 5a). The HSI of females was the highest in January $(1.35 \pm 0.08 \%)$ and the lowest $(0.55$ $\pm 0.06 \%$ ) in May (Fig. 5a). A significant decrease in the HSI from January to February was followed by significantly lower values until August which coincided with the breeding period (Mann-Whitney test; $P>0.05)$. Thereafter, the HSI increased from September till December (Fig. 5a). In males, a similar trend was observed with a significant difference in the HSI across the year (Kruskal-Wallis test, $H=94.26$; $P=0.0001$; Fig. $5 b)$. The HSI for males ranged from $0.26-0.98 \%$ with the highest value in January $(0.98 \pm$ $0.06 \%)$ and the lowest $(0.26 \pm 0.02 \%)$ in March (Fig. 5b). Significantly lower HSI was observed from February to August and in November (Mann-Whitney test; $P<0.05)$. Thereafter, the HSI values increased until January.

\section{Stomach fullness index (SFI)}

In females, the SFI varied significantly across the year (Kruskal-Wallis test, $H=59.31 ; P=0.0001 ;$ Fig. $5 c$ ) and followed a trend which coincided with the breeding period. A significant decrease in the SFI was observed from February to June (Mann-Whitney test; $P<0.05$ ). Thereafter, a steady rise in the SFI was observed until December with a significant difference across the months $(P<0.05$; Fig. $5 \mathrm{c})$. In the case of males, though the SFI showed significant difference across the months (Kruskal-Wallis test, $H=85.2 ; P=0.0001$; Fig. 5d), no trend was observed. Significantly lower SFI was observed only in March, May, August, and September (Mann-Whitney test; $P<0.05$; Fig. $5 d$ ).

\section{Size at first maturity}

The length at which $50 \%$ of females were sexually mature ( $\left.T L_{50}\right)$ was $8.9 \mathrm{~cm}$ and this was considered to be the size at first maturity (Fig. 6a). The histological evidence confirmed that females larger than $8.9 \mathrm{~cm}$ were in different reproductive phases depicting maturity. These fish had developing ovary (Fig. 6b), capable of spawning (Fig. 6c), or actively spawning (Fig. 6d), and resting ovary (Fig. 6e). The descriptions of the characteristic features of each reproductive phase are provided in Table 2.

The length at which $50 \%$ of males were sexually mature ( $\left.T L_{50}\right)$ was $7.3 \mathrm{~cm}$ which was considered as the size of the first maturity (Fig.7a). Males that were smaller than $7.3 \mathrm{~cm}$ showed the presence of spermatogenic tissue (Fig. 7b) whereas males that were larger than $7.3 \mathrm{~cm}$ possessed spermatozoa and thus, were considered as mature (Fig. 7c). 


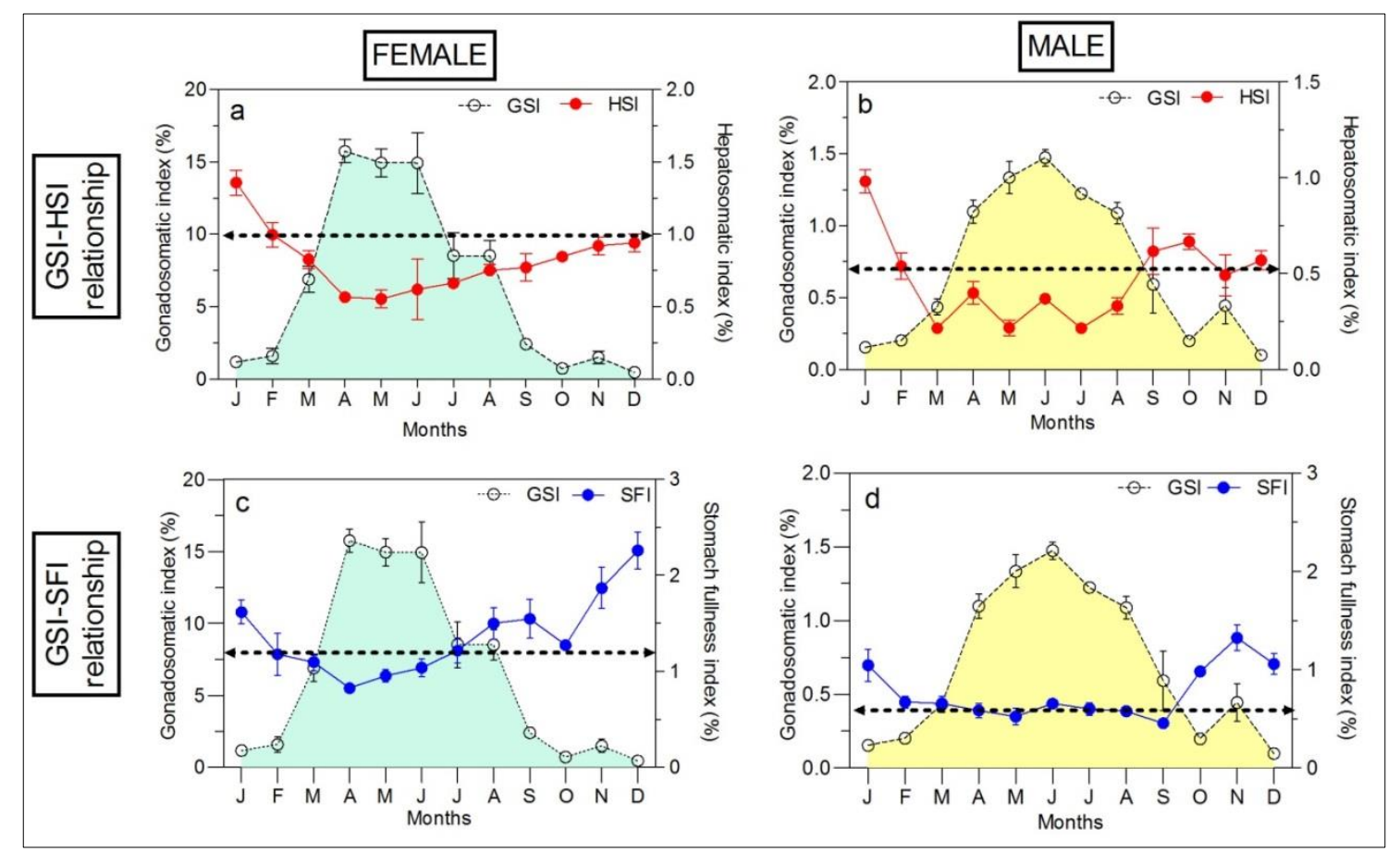

Fig. 5. Monthly variation patterns of the hepatosomatic index $(H S I)(a, b)$ and the stomach fullness index (SFI) (c, d) against the gonadosomatic index (GSI) for females (left) and males (right) of Pachypterus khavalchor. The values on or above the horizontal black dotted lines are statistically significant.
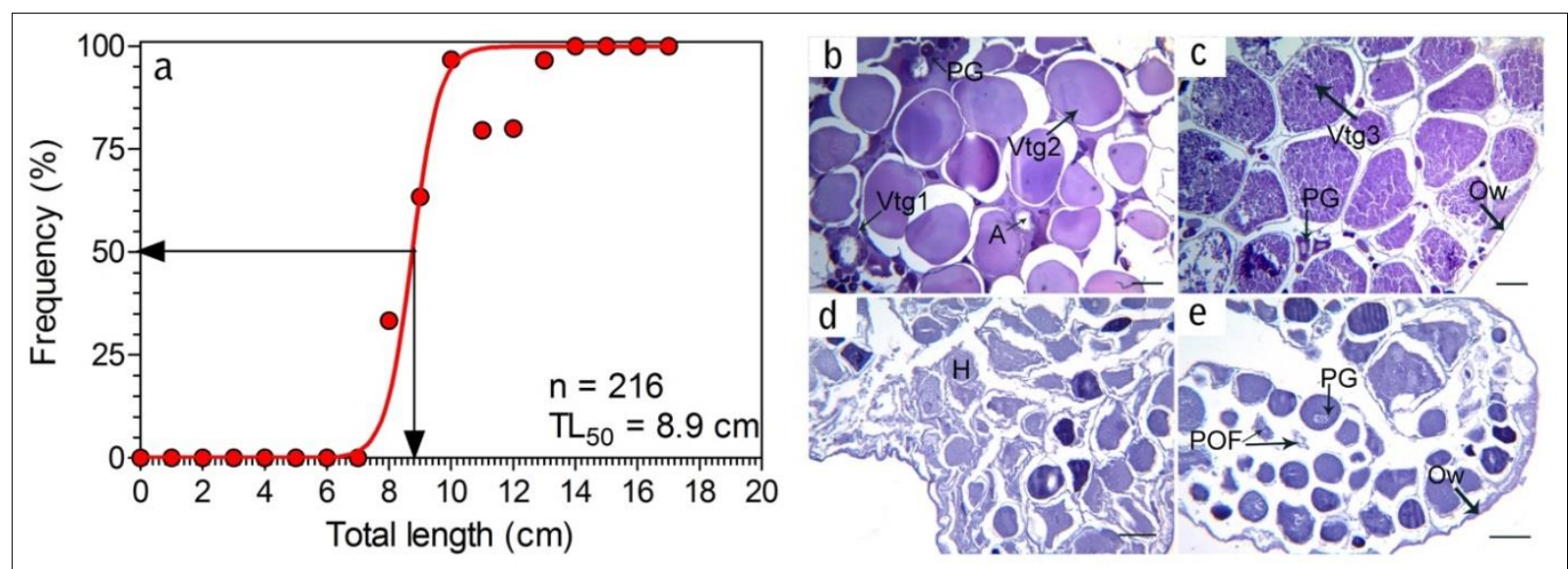

Fig. 6. Sexual maturity and various reproductive phases of female Pachypterus khavalchor in the Panchaganga River, Maharashtra, India. (a) Size at first maturity ( $\mathrm{LL}_{50}$ ) curve for female, (b) Developing ovary with primary growth (PG) oocyte and vitellogenic oocytes stage 1 ( Vtg 1) and stage 2 (Vtg 2), (c) Spawning capable ovary with thin ovary wall (Ow) and stage 3 vitellogenic oocytes (Vtg 3), (d) Actively spawning individual with hydrated (H) oocytes, (e) Resting individual with evidence of recent spawning including postovulatory follicles (POF), absence of vitellogenic oocytes and thick ovary wall (Ow). Scale bar $=$ $100 \mu \mathrm{m}$.

Table 2. Reproductive state classification scheme for female Pachypterus khavalchor (Kulkarni, 1952).

\begin{tabular}{|c|c|c|}
\hline $\begin{array}{l}\text { Reproductive } \\
\text { state }\end{array}$ & $\begin{array}{l}\text { Maturity } \\
\text { status }\end{array}$ & Distinguishing features \\
\hline Undeveloped & Immature & Presence of thin ovary wall, early-stage oogonia, and primary growth (PG) oocytes. \\
\hline Developing & Mature & Primary growth oocytes (PG) could be observed along with early vitellogenic oocytes (Vtg) stage I and/or II. \\
\hline $\begin{array}{l}\text { Spawning } \\
\text { capable }\end{array}$ & Mature & $\begin{array}{l}\text { Presence of vitellogenic oocytes (Vtg IIII) could be identified by ample of granular yolk filled in } \\
\text { comparatively larger oocytes. }\end{array}$ \\
\hline $\begin{array}{l}\text { Actively } \\
\text { spawning }\end{array}$ & Mature & $\begin{array}{l}\text { Presence of hydrated oocytes. Presence of post-ovulatory follicles (POFs) along with few retained } \\
\text { oocytes post-spawning. }\end{array}$ \\
\hline Resting & Mature & $\begin{array}{l}\text { Marked by regenerating ovary, presence of thick ovary wall, absence of vitellogenic oocytes, and } \\
\text { presence of postovulatory follicles (POFs). }\end{array}$ \\
\hline
\end{tabular}




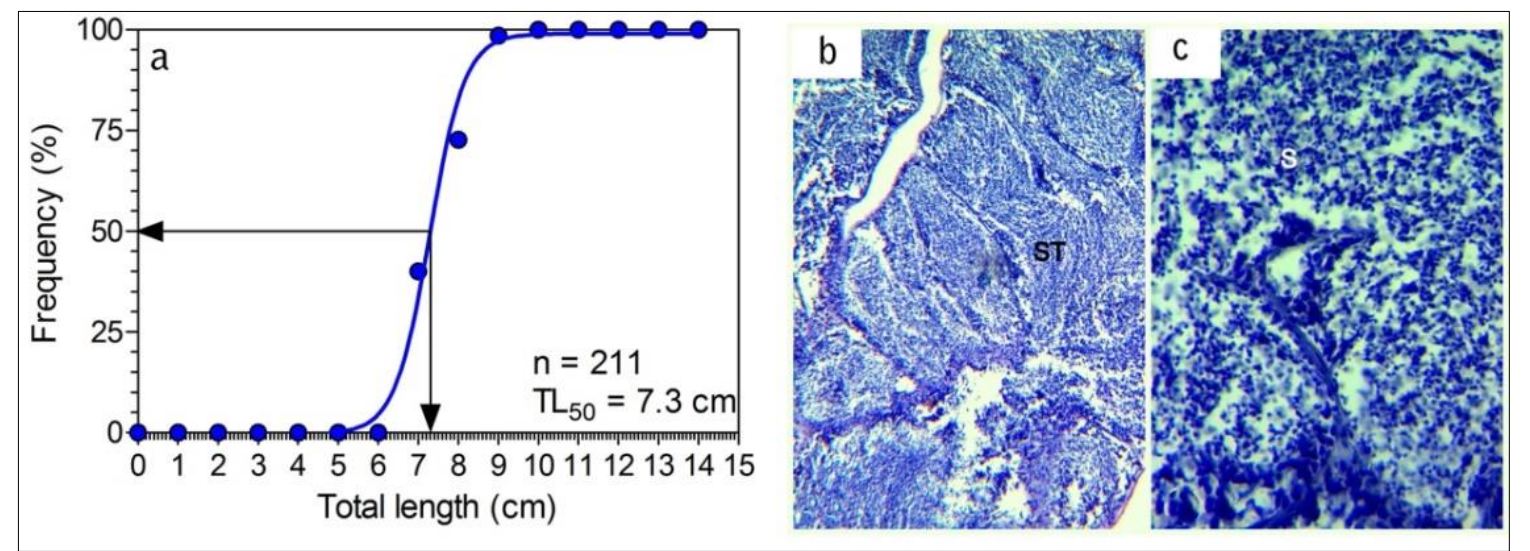

Fig. 7. Sexual maturity and various reproductive phases of male Pachypterus khavalchor in the Panchaganga River, Maharashtra, India. (a) Size at first maturity (TL50) curve for male, (b) Immature male with spermatogenic tissue (ST), (c) Mature male with spermatozoa(S). Scale bar $=100 \mu \mathrm{m}$.

\section{Fecundity}

The ranges and average values of $\mathrm{SL}, \mathrm{TL}, \mathrm{Wt}, \mathrm{OW}, \mathrm{OL}$, fecundity and relative fecundity have been presented in Table 3.

The mean fecundity was $7305 \pm 1222$ eggs and ranged from 933 to 24642 eggs. Relative fecundity ranged from 226 to 723 eggs. g $^{-1}$ of body weight (Mean \pm SE = $432 \pm 29$ eggs. $g^{-1}$ of body weight). The correlations of absolute fecundity (F) with standard length (SL; Fig. 8a), body weight (Wt; Fig. 8b), ovary weight (OW; Fig. 8c) and ovary length (OL; Fig. 8d) were found to be highly significant $(P<0.0001)$.

Table 3. Summary of estimated fecundity parameters of Pachypterus khavalchor $(n=30)$.

\begin{tabular}{llllllll}
\hline Range & $\begin{array}{l}\mathrm{SL} \\
(\mathrm{cm})\end{array}$ & $\begin{array}{l}\mathrm{TL} \\
(\mathrm{cm})\end{array}$ & $\begin{array}{l}\text { Wt } \\
(\mathrm{g})\end{array}$ & $\begin{array}{l}\text { OW } \\
(\mathrm{g})\end{array}$ & $\begin{array}{l}\text { OL } \\
(\mathrm{cm})\end{array}$ & $\begin{array}{l}\text { Fecundity } \\
(\text { eggs.fish }\end{array}$ & $\begin{array}{l}\text { Relative fecundity } \\
\left(\text { eggs.g } \text { - }^{-1} \text { of BW }\right)\end{array}$ \\
\hline Min-Max & $6.44-12.59$ & $7.55-15.54$ & $3.6-36.9$ & $0.21-6.66$ & $1.22-4.37$ & $932-24642$ & $226-723$ \\
\hline $\begin{array}{l}\text { Mean } \pm \\
\text { SE }\end{array}$ & $9.41 \pm 3.47$ & $11.58 \pm 4.24$ & $15.4 \pm 1.93$ & $1.94 \pm 0.35$ & $2.66 \pm 1.46$ & $7304 \pm 1222$ & $432 \pm 29$ \\
\hline
\end{tabular}

Avg, Average; SL, Standard length; TL, Total length; Wt, Body weight; OW, Ovary weight; OL, Ovary length; Min, Minimum; Max, Maximum.
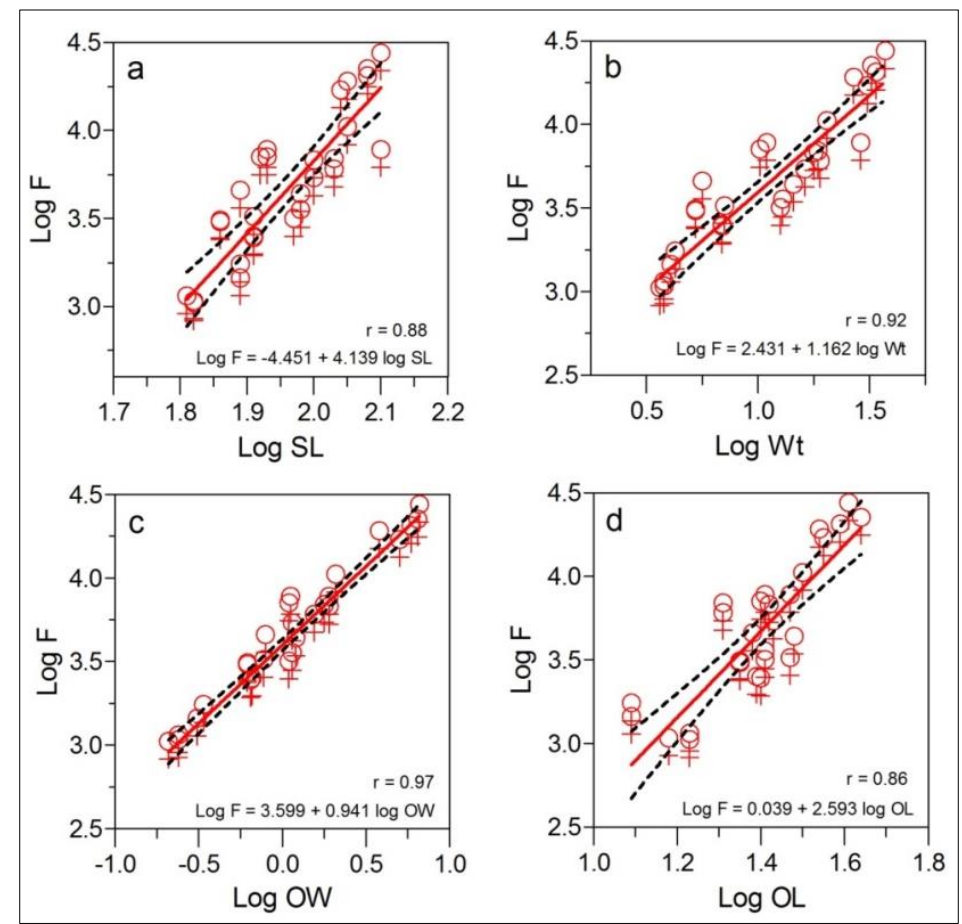

Fig. 8. Relationship between absolute fecundity (F) and standard length (a), Weight (b), Ovary weight (c), Ovary length (d) for Pachypterus khavalchor from River Panchaganga, India. The black dotted lines indicate $95 \%$ confidence intervals. 
No significant correlation (Pearson $r=0.2657 ; \mathrm{Cl}$ : 0.1047 to $0.5713 ; r^{2}=0.0706, P=0.1559$, Fig. 9) was observed between the standard length of fish and relative fecundity suggesting no effect of standard length on fecundity.

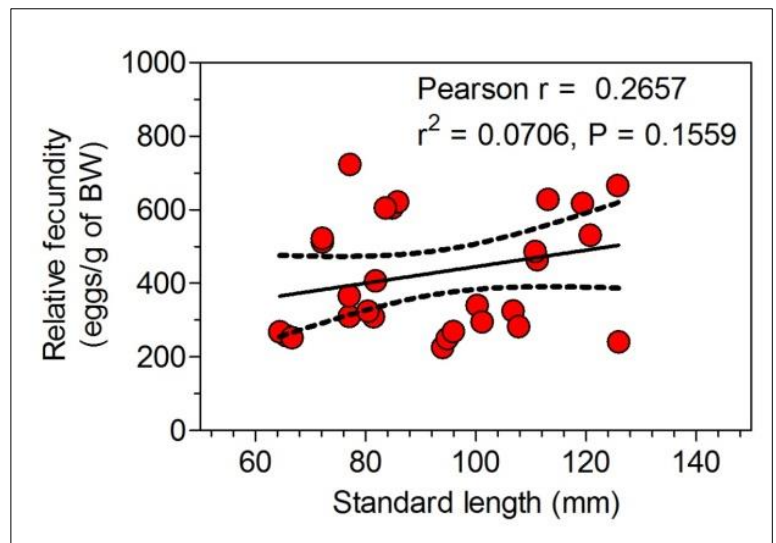

Fig. 9. Relationship between relative fecundity and standard length for Pachypterus khavalchor from River Panchaganga, India. The black dotted lines indicate $95 \%$ confidence intervals.

\section{Condition factor}

The mean values of the condition index $(K)$ were found to be $0.882,1.034,1.028$, and 0.909 in winter, premonsoon, monsoon, and post-monsoon seasons respectively. A significant difference was observed in the condition index across the various seasons [ANOVA $\left(F_{3,424}\right)=50.36$; $P<0.0001$; Fig. 10] in $P$. khavalchor. Post-hoc tests revealed no significant difference between the ' $K$ ' values of winter and postmonsoon ( $P>0.05$; Fig. 10). However, the ' $K$ ' values of $P$. khavalchor were found to be significantly higher during pre-monsoon and monsoon ( $P<0.05$; Fig. 10) as compared to winter and post-monsoon.

\section{Discussion}

Knowledge of the reproductive characteristics of fishes is crucial for recognising the stocks and their management (Lucifora et al., 1999; Lee et al., 2005; Liu et al., 2013). Sexual dimorphism has been reported in several fish groups, including catfishes (Doha, 1974; Oliveira and Almada, 1995; Musa and Bhuiyan, 2006; Esmaeili et al., 2017). Males of $P$. khavalchor showed a clear morphological character representing sexual dimorphism. A similar structure has also been observed in other members of the Schilbeidae family, such as African butter catfish (Schilbe mystus (Linnaeus, 1758)), silver catfish (Schilbe intermedius (Rüppell, 1832)), and African glass catfish (Parailia pellucida (Boulenger, 1901)) (Olatunde, 1978; Ayoade, 2009). Genital papillae generally control gamete release and thus ensure the higher fertilisation rate (Rosotto and Shapiro, 1998). Sex-based variation in size classes signifies sexual segregation in $P$. khavalchor. Although the overall percentage of both sexes during the study period was $50 \%$, the monthly sex ratio showed a deviation from 1:1 ratio in some months. Such variation in male to female sex ratio could be attributed to several factors, such as differential growth rates, different longevity of males and females, sex reversal, migrations, use of different gears for sampling, sampling sites, and aggregation behaviour of the species (Dadzie and Wangila, 1980; Avoade, 2009; Bindu et al., 2012). The observed differences in the present study could be due to any single factor or the synergistic effect of multiple factors.

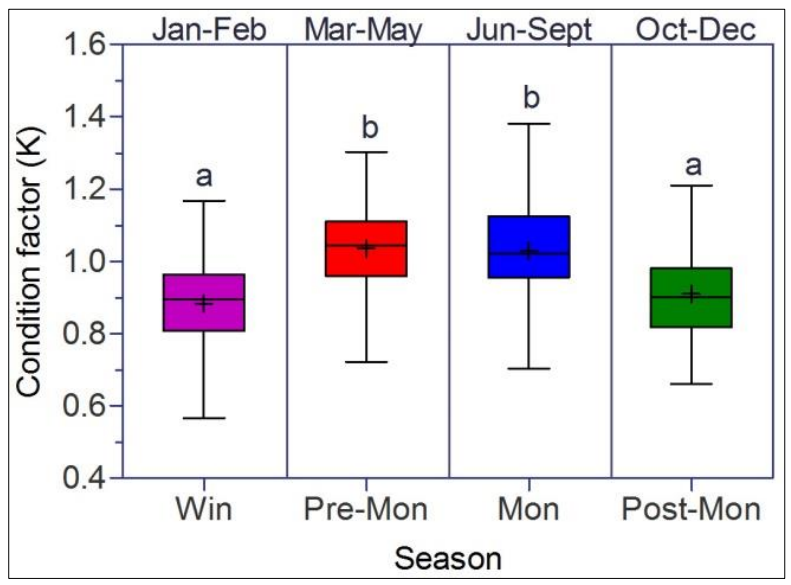

Fig. 10. Condition factor (K) of Pachypterus khavalchor (pooled data) sampled seasonally in the Panchaganga River tributary of the Krishna River system, India. Winter (Win), January-February; Pre-monsoon (Pre-Mon), March to May; Monsoon (Mon), June to September; Post-monsoon (PostMon), October to December. ' + ' within the box indicates the mean value of the condition factor for that season. The horizontal line within the box indicates the median value for that season. Different letters indicate significant differences between the categories.

The gonado-somatic index is one of the most useful measures to identify gonadal maturity and the breeding season of any fish species (Bindu et al., 2012; Raghavan et al., 2016; Ogunola et al., 2018). The GSI is known to increase with maturity and decreases with the depletion of gonadal activity after spawning (Bindu et al., 2012; Jan et al., 2014; Geremew et al., 2015). Based on the present investigation, it is clear that $P$. khavalchor has a prolonged breeding period extending from April to August. Similar findings were also documented for Horabagrus brachysoma (Günther, 1864), which has a breeding period from May to early August (Bindu et al., 2012; Chandran and Prasad, 2014). The extended breeding seasons in tropical species as compared to their temperate counterparts have been documented in many groups, including mammals, birds, reptiles, amphibians, and marine invertebrates (Kramer, 1978). This indicates that, when the physical conditions are favourable, the benefits of an extended breeding season are typically greater than those of a short, highly synchronised 
reproductive period. Poeciliids (Turner, 1938) and some lacustrine cichlids (Fryer and Iles, 1972) are wellknown for their long or continuous breeding seasons. On the contrary, the cyprinoids, characoids, and siluroids which make up by far the majority of tropical freshwater species (Roberts, 1972), appear to be extremely seasonal, generally cueing their reproduction to the floods of the early rainy season. The extended breeding period could be an evolutionary adaptation in order to take advantage of both pre-monsoon and monsoon seasons and also provides the opportunity for the females to release all the eggs in one season (Zamidi et al., 2012). Additionally, a prolonged breeding season could maximise offspring survival during the early lifehistory stages (Zhang et al., 2012). Although temperature and rainfall are the key environmental factors affecting the reproductive periodicity, in $P$. khavalchor, the reproductive cycle is likely to be regulated by rainfall alone (Bauer, 1992). The study area receives continuous rainfall from May to November due to its proximity to the Western Ghats. According to Ahamed et al. (2018), rainfall not only provides optimum conditions for fishes by lowering the temperature and increasing the dissolved oxygen content of water, but also promotes hydration in the fishes and their gonads to induce natural spawning.

The hepato-somatic index provides information on total energy reserves and fish condition (Lubzens et al., 2010). The results of the present study revealed that the reproductive periodicity and $\mathrm{HSI}$ in $P$. khavalchor are strongly correlated. In females, the liver contributes to reproduction by synthesising the protein vitellogenin (Lubzens et al., 2010). A steady increase of HSI from September to January could be due to the synthesis of vitellogenin in the liver. On the contrary, the sudden decline in the HSI in February and the continuous low values of the HSI thereafter could be due to the main spawning season in $P$. khavalchor. In males, a very similar but relatively weak temporal trend was observed in both the HSI and the GSI. The stomach fullness index was negatively correlated with the GSI, suggesting that $P$. khavalchor decreases their feeding activity as the breeding season approaches. In females, during the peak breeding period (March to July) the SFI decreases drastically. This could be related to the additional requirement for females to have room in the abdominal cavity to accommodate the enlarged gonads as a result of oocyte maturation (Lubzens et al., 2010; Ogunola et al., 2018). In males, a relatively weak temporal trend was observed between GSI and SFI.

Size at sexual maturity is crucial for fishery resource management since it provides the power to decide the mesh size in the fishing grounds and thus, prevent overfishing (Lucifora et al., 1999; Lee et al., 2005; Hossain et al., 2013). The use of appropriate mesh size will prevent the cropping of immature individuals and thus, avoid reducing the reproductive potential
(Hossain et al., 2013; Liu et al., 2013). Early maturation of males with a relatively smaller size as compared to females is a common phenomenon in tropical fishes and is likely to be associated with sex-specific growth rate (Lee et al., 2005; Bindu et al., 2012; Hossain et al., 2013; Ogunola et al., 2018).

The estimation of fecundity is the most common parameter for many tropical fish species (Lagler, 1966; Lee et al., 2005; Liu et al., 2013; Ogunola et al., 2018). Information on fecundity forms can be effectively used for fisheries management to recover the exploited fish stocks (Lagler, 1966; Lee et al., 2005; Liu et al., 2013). The mean fecundity of $P$. khavalchor in the Panchaganga River was $7305 \pm 6698$ eggs. fish ${ }^{-1}$. The lack of data on P. khavalchor fecundity from other locations limits our comparisons. However, the Asian sun catfish, H. brachysoma, another member of the family Horabagridae, has the highest absolute fecundity of 1140 oocytes fish ${ }^{-1}$ and is known to be highly fecund (Bindu et al., 2012). Based on a comparative analysis of the fecundity of these two species, P. khavalchor could be considered a highly fecund species. Breder and Rosen (1966) and Froese and Pauly, (2018), reported higher fecundity is associated with a lack of parental care. Thus, a similar situation could be for P. khavalchor, which showed high fecundity. Variation in fecundity among the members of the same family could be associated with several factors such as the amount of rainfall, the concentration of dissolved oxygen, water temperature, food availability, and fishing pressure (Koslow et al., 1995; Ogunola et al., 2018). A positive correlation between fecundity and fish length, body weight, ovary length, and ovary weight is common among fishes (Jan et al., 2014; Geremew et al., 2015). Larger individuals can devote more energy to gonad development as compared to small individuals and thus, can have relatively higher fecundity. Larger females are known to produce more eggs (Sivakumaran et al., 2003); however, a lack of correlation between the relative fecundity and the standard length of individuals suggests that there is no effect of standard length on fecundity in $P$. khavalchor.

The condition factor $(K)$ is an index reflecting the interactions between biotic and abiotic factors on the physiological condition of the fishes (Le Cren, 1951; Hossain et al., 2013). The ' $K$ ' values in the present study varied between 0.56 and 1.38. According to Bagenal (1978), individuals with higher K values (> 1) are in a better condition than those with lower $\mathrm{K}$ values (< 1). The significantly higher ' $K$ ' values observed during the pre-monsoon and monsoon seasons could be attributed to the reproductive periodicity of the species as the condition factor reflects not only the nutritional status of the fish but also indicates the state of gonadal development (Vazzoler and Vazzoler, 1965; Ogunola et al., 2018). Fishes usually decrease their feeding activity to allocate extra space in the abdominal cavity to store eggs. The use of lipid 
reserves during spawning (Lizama and Ambrosio, 2002) leads to gonadal growth, which ultimately represents their higher weight gain and better health. This suggests that the higher values of the condition factor shown by $P$. khavalchor during the premonsoon and monsoon season could be due to an increase in gonad weight. The ' $K$ ' value is also known to be affected by biotic factors such as availability of food, predation rate, and prevalence of diseases in the environment as well as abiotic factors such as temperature, $\mathrm{pH}$, and pollution of the aquatic bodies from various anthropogenic factors (Wang et al., 2017). Although there is currently no comprehensive data on the biotic and abiotic factors of the study site, the low ' $\mathrm{K}$ ' values observed during the post-monsoon and winter seasons may be the effect of a single factor or multiple factors operating synergistically. Further studies considering the effect of biotic and abiotic factors on fish condition factor would be useful in this regard.

\section{Conclusion}

Due to limited knowledge of biology, the rare occurrence, high fishing pressure, threats from variety of anthropogenic factors and a highly fragmented population of $P$. khavalchor, this study provides fundamental information on the life-history traits that have both conservation and aquaculture implications. Males mature at smaller sizes than the females and can be distinguished by a sexually dimorphic character. Females are highly fecund and have a prolonged breeding season which starts in March and continues until August. The effect of reproductive periodicity on the condition factor was evident. The major implications of the present study are as follows: (a) due to exploited status of fishery, the estimated breeding season (March - April) can be declared as the close seasons for the fishery to restored the exploited stocks, (b) the estimated size of maturity will allow aquaculture experts to predict the spawning season to enable policymakers and fisheries managers decide on the mesh-sizes application, (c) the evidence of spawning during monsoon and high fecundity guide the aquaculture experts in assessing the best time to pull egg mass for hatching.

\section{Acknowledgements}

We acknowledge Swapnil Choudhary, Manoj Pise, Pankaj Gorule and Chandani Verma for logistic support and field assistance. We also thank the anonymous reviewers and editorial board members for their valuable comments on the earlier version of the manuscript, which significantly improved and fine-tuned the manuscript. Thanks are also due to Swetashree Kolay for her help in improving the language quality of the manuscript. The current study received financial support from the Department of Biotechnology (DBT), Government of India, New Delhi, India under DBT-STAR college scheme and the
Department of Science and Technology (DST), Government of India, New Delhi, India under DST-FIST grants sanctioned to the Modern College of Arts, Science and Commerce, Ganeshkhind, Pune, India.

\section{References}

Ahamed, F., Saha, N., Nishat, M.A., Biswas, M.K., Sultana, M., Khatun, M.S., Ahmed, Z.F., Hossain, M.Y., Ohtomi, J. 2018. Length-weight and length-length relationships of three small indigenous fishes from the Payra River, southern Bangladesh. Journal of Applied Ichthyology 34:777-779. https://doi.org/10.1111/jai.13642

Ayoade, A. A. 2009. Aspects of the reproductive biology of the African butter catfish Schilbe mystus (Teleostei: Schilbeidae) in an artificial lake in south western Nigeria. Zoologist 7:130-140.

Bagenal, T. 1978. Methods for assessment of fish production in fresh waters. Blackwell Scientific Publications, London. 300 pp.

Bauer, R.T. 1992. Testing generalization about latitudinal variation in reproduction and recruitment patterns with sicyoniid and caridean shrimp species. Invertebrate Reproduction and Development 22:193-202.

Bindu, L., Padmakumar, K.G., Sreerekha, P.S., Joseph, N. 2012. Reproductive biology of the golden catfish, Horabagrus brachysoma (Günther, 1864), an endemic species of the Western Ghats, India. Journal of Applied Ichthyology 28:772-777. https://doi.org/10.1111 /j.1439-0426.2012.02026.x

Breeder, C.M., D.E. Rosen. 1966. Modes of reproduction in fishes. Natural History Press, Garden City, NY, USA. 941 pp.

Brown-Peterson, N.J., Wyanski, D.M., Saborido-Rey, F., Macewicz, B.J., Lowerre-Barbieri, S.K. 2011. A standardized terminology for describing reproductive development in fishes. Marine and Coastal Fisheries 3:52-70. https://doi.org/10.1080/19425120.2011.555724

Chandran, L.R., Prasad, G. 2014. Reproductive characters of yellow catfish Horabagrus brachysoma (Horabagridae) from Periyar River, Western Ghats. Journal of Aquatic Biology and Fisheries 2:154-161.

Dadzie, S., Wangila, B.C.C. 1980. Reproductive biology, length-weight relationship and relative condition of pond raised Tilapia zilli (Gervais). Journal of Fish Biology 17:243-254. https://doi.org/10.1111 /j.1095-8649.1980.tb02758.x

Dahanukar, N. 2011. Neotropius khavalchor. The IUCN Red List of Threatened Species 2011:152 e.T172310A6864780. https://www.iucnredlist.org/species/172310/6864780. (Accessed 01 March 2020).

Dahanukar, N., Paingankar, M., Raut, R.N., Kharat, S.S. 2012. Fish fauna of Indrayani River, northern Western Ghats, India. Journal of Threatened Taxa 4: 2310-2317.

Doha, S. 1974. Investigation in to the biology of the gobi, Glossogobius giuris (Hamilton-Buchanan) (Perciformes: Gobidae). Bangladesh Journal of Zoology 2:95-106.

Esmaeili, H.R., Sayyadzadeh, G. Chermahini, M.A. 2017. Sexual dimorphism in two catfish species, Mystus pelusius (Solander, 1794) and Glyptothorax silviae Coad, 1981 (Teleostei: Siluriformes). Turkish Journal of Zoology 41:144-149. https://doi.org/10.3906/zoo-1509-22

Froese, R. 2006. Cube law, condition factor and weight-length relationships: History, meta-analysis and recommendations. Journal of Applied Ichthyology 22:241-253. https://doi.org/10.1111/j.14390426.2006.00805.x

Froese, R., Pauly, D. 2018. FishBase. World Wide Web electronic publication. www. fishbase.org (Accessed on 01 March 2020).

Fryer, G., Iles, T.D. 1972. The cichlid fishes of the Great Lakes of Africa. Their biology and evolution. Oliver and Boyd, Edinburgh. 158 pp. 
Geremew, A., Getahun, A., Dejen, E. 2015. Reproductive biology of Garra regressus and Garra tana (Cypriniformes: Cyprinidae) from Lake Tana, Ethiopia. Journal of Threatened Taxa 7:7223-7233. https://doi.org/10.11609/JoTT.03958.7223-33

Gosavi, S.M., Kharat, S.S., Kumkar, P., Navarange, S.S. 2018. Interplay between behavior, morphology and physiology supports lepidophagy in the catfish Pachypterus khavalchor (Siluriformes: Horabagridae). Zoology 126:185-191. https://doi.org/10.1016/j.zool.2017.07.003

Gosavi, S.M., Verma, C.R., Kharat, S.S., Pise, M., Kumkar, P. 2019a. Structural adequacy of the digestive tract supports dual feeding habit in catfish Pachypterus khavalchor (Siluriformes: Horabagridae). Acta Histochemica 121:437-449. https://doi.org/10.1016 /j.acthis.2019.03.006

Gosavi, S.M., Kharat, S.S., Kumkar, P., Tapkir, S.D. 2019b. Assessing the sustainability of lepidophagous catfish, Pachypterus khavalchor (Kulkarni, 1952), from a tropical river Panchaganga, Maharashtra, India. The Journal of Basic and Applied Zoology 80:9. https://doi.org /10.1186/s41936-019-0080-8

Hammer, Ø., Harper, D.A.T., Ryan, P.D. 2001. PAST: Paleontological statistics software package for education and data analysis. Palaeontologia Electronica 4:9. http://palaeo-electronica.org /2001_1/past/issue1_01.htm

Hossain, M.Y., Hossen, M.A., Islam, M.S., Jasmine, S., Nawer, F., Rahman, M.M. 2017. Reproductive biology of Pethia ticto (Cyprinidae) from the Gorai River (SW Bangladesh). Journal of Applied Ichthyology 33:1007-1014. https://doi.org/10.1111/jai.13427

Hossain, M.Y., Arefin, M.S., Mohmud, M.S., Hossain, M.I., Jewel, M.A.S., Rahman, M.M., Ahamed, F., Ahmed, Z.F., Ohtomi, J. 2013. Lengthweight relationships, condition factor, Gonadosomatic-index based size at first sexual maturity, breeding season and fecundity of Aspidoparia morar (Cyprinidae) in the Jamuna River (Brahmaputra River distributary), northern Bangladesh. Journal of Applied Ichthyology 29:1166-1169. https://doi.org/10.1111/jai.12127

Jadhav, B.V., Kharat, S.S., Raut, R.N., Paingankar, M., Dahanukar. N. 2011. Freshwater fish fauna of Koyna River, northern Western Ghats, India. Journal of Threatened Taxa 3:1449-1455. https://doi.org /10.11609/JoTT.02613.1449-55

Jan, M., Jan, U., Shah, G.M. 2014. Studies on fecundity and gonadosomatic index of Schizothorax plagiostomus (Cypriniformes: Cyprinidae). Journal of Threatened Taxa 6:5375-5379. https://doi.org/10.11609/JoTT.03269.5375-9

Koslow, J.A., Bell, J., Virtue, P., Smith, D.C. 1995. Fecundity and its variability in orange roughy: effects of population density, condition, egg size, and senescence. Journal of Fish Biology 47:1063-1080. https://doi.org/10.1111/j.1095-8649.1995.tb06030.x

Kramer, D.L. 1978. Reproductive seasonality in the fishes of a tropical stream. Ecology 59:976-985. https://doi.org/10.2307/1938549

Kulkarni, C. 1952. A new genus of schilbeid catfishes from the Deccan. Records of the Indian Museum 49:231-238.

Kumbar, S.M., Lad, S.B. 2014. Diversity, threats and conservation of catfish fauna of the Krishna River, Sangli District, Maharashtra, India. Journal of Threatened Taxa 6:5362-5367. https://doi.org /10.11609/JoTT.03394.5362-7

Lagler, K.F. 1966. Freshwater fishery biology. W.M.C. Brown Co., lowa. $421 \mathrm{pp}$.

Le Cren, E.D. 1951. The length-weight relationship and seasonal cycle in gonad weight and condition in the perch (Perca fluviatilis). The Journal of Animal Ecology 20:201-219. https://doi.org/10.2307/1540

Lee, C.F., Liu, K.M., Su, W.C., Wu, C.C. 2005. Reproductive biology of the common ponyfish Leiognathus equulus in the south-western waters off Taiwan. Fisheries Science 71:551-562. https://doi.org /10.1111/j.1444-2906.2005.00999.x
Liu, C., Gao, X., Wang, H., Liu, H., Cao, W., Danley, P.D. 2013. Reproductive characteristics of Ancherythroculter nigrocauda, an endemic fish in the upper Yangtze River, China. Fisheries Science 79:799-806. https://doi.org/10.1007/s12562-013-0656-z

Lizama, M.D.L.A.P., Ambrosio, A.M. 2002. Condition factor in nine species of fish of the Characidae family in the upper Paraná river floodplain, Brazil. Brazilian Journal of Biology 62:113-124. https://doi.org/10.1590/S1519-69842002000100014

Lubzens, E., Young, G., Bobe, J., Cerda, J. 2010. Oogenesis in teleosts: how fish eggs are formed. General and Comparative Endocrinology 165:367-389. https://doi.org/10.1016/j.ygcen.2009.05.022

Lucifora, L.O., Valero, J.L., Garcia, V.B. 1999. Length at maturity of the green-eye spurdog shark, Squalus mitsukuii (Elasmobranchii: Squalidae) from the SW Atlantic, with comparisons with other regions. Marine and Freshwater Research 50:629-632. https://doi.org/10.1071/MF98167

Menon, A.G.K. 2004. Threatened fishes of India and their conservation. Zoological Survey of India, Kolkata. 170 pp.

Musa, A.S.M., Bhuiyan, A.S. 2006. Determination of sexual dimorphism in Mystus bleekeri (Day). University Journal of Zoology Rajshahi University 25:65-66. https://doi.org/10.3329/ujzru.v25i0.331

Ogunola, O.S., Onada, O.A., Falaye, A.E. 2018. Preliminary evaluation of some aspects of the ecology (growth pattern, condition factor and reproductive biology) of African pike, Hepsetusodoe (Bloch 1794), in Lake Eleiyele, Ibadan, Nigeria. Fisheries and Aquatic Sciences 21:12. https://doi.org/10.1186/s41240-018-0087-y

Olatunde, A.A. 1978. Sex, reproductive cycle and variations in the fecundity of the family schilbeidae (Osteichthyes: Siluriformes) in Lake Kainji, Nigeria. Hydrobiologia 57:125-142. https://doi.org /10.1007/BF00016456

Oliveira, R.F. Almada, V.C. 1995. Sexual dimorphism and allometry of external morphology in Oreochromis mossambicus. Journal of Fish Biology 46:1055-1064. https://doi.org/10.1111/j.1095-8649.1995 .tb01409.x

Raghavan, R., Philip, S., Ali, A., Katwate, U., Dahanukar, N. 2016. Fishery, biology, aquaculture and conservation of the threatened Asian Sun catfish. Reviews in Fish Biology and Fisheries 26:169-180. https://doi.org/10.1007/s11160-016-9418-1

Rasotto, M.B., Shapiro, D.Y. 1998. Morphology of gonoducts and male genital papilla, in the bluehead wrasse: implications and correlates on the control of gamete release. Journal of Fish Biology 52:716-725. https://doi.org/10.1111/j.1095-8649.1998.tb00815.x

Ricker, W.E. 1975. Computation and interpretation of biological statistics of fish populations. Bulletin of the Fisheries Research Board of Canada, Bulletin 191, Ottawa, Canada. 382 pp.

Roberts, T.R. 1972. Ecology of fishes in the Amazon and Congo basins. Bulletin of the Museum of Comparative Zoology 143:117-147.

Simpson, A.C. 1959. Method used for separating and counting eggs in fecundity studies on herring (Clupea harengus). FAO Indo-Pacific Fisheries Council, Occasional paper 59/12. 3 pp.

Sivakumaran, K.P., Brown, P., Stoessel, D., Giles, A. 2003. Maturation and reproductive biology of female wild carp, Cyprinus carpio, in Victoria, Australia. Environmental Biology of Fishes 68:321-332. https://doi.org/10.1023/A:1027381304091

Turner, C.L. 1938. The reproductive cycle of Brachyraphi sepiscopi, an ovoviviparous poeciliid fish, in the natural tropical habitat. Biology Bulletins 75:56-65. https://doi.org/10.2307/1537672

Vazzoler, A.D.M., Vazzoler, G. 1965. Relation between condition factor and sexual development in Sardinella aurita (Cuv. \& Val. 1847). Annals of the Brazilian Academy of Sciences 37:353-359.

Wang, L., Wu, Z., Liu, M., Liu, W., Zhao, W., Liu, H., Zhang, P., You, F. 2017. Length-weight, length-length relationships, and condition 
factors of black rockfish Sebastes schlegelii Hilgendorf, 1880 in Lidao Bay, China. Thalassas: An International Journal of Marine Sciences 33:57-63. https://doi.org/10.1007/s41208-017-0021-6

Zamidi, I., Samat, A., Zaidi, C.C., Mazlan, A.G., Alam, G.M., Al-Amin, A.O. Simon, K.D. 2012. Fecundity and temporal reproductive cycle of four finger threadfin (Eleuthero nematetradactylum) in Malaysian coastal water. Asian Journal of Animal and Veterinary Advances 7:1100-1109. https://doi.org/10.3923/ajava.2012.1100.1109

Zhang, G., Wu, L., Li, H.T., Liu, M., Cheng, F., Murphy, B.R, Xie, S.G. 2012 Preliminary evidence of delayed spawning and suppressed larval growth and condition of the major carps in the Yangtze River below the Three Gorges Dam. Environmental Biology of Fishes 93:439-447. https://doi.org/10.1007/s10641-011-9934-8 